\title{
Lantana camara: Poisonous Species and a Potential Browse Species for Goats in Southern Africa-A Review
}

\author{
Malizo Ntalo ${ }^{1,2, *\left(\mathbb{D} \text {, Khuliso Emmanuel Ravhuhali }{ }^{1,2} \mathbb{D} \text {, Bethwell Moyo }{ }^{3} \text {, Onke Hawu }\right.}$, $^{1, *} *$ (D) \\ and Ntokozo Happy Msiza 1,2 (D)
}

1 Department of Animal Science, School of Agricultural Sciences, Faculty of Natural and Agricultural Sciences, North West University, Mmabatho 2735, South Africa; ravhuhalike@gmail.com (K.E.R.); happy.msiza@yahoo.com (N.H.M.)

2 Food Security and Safety Niche Area, Faculty of Natural and Agricultural Sciences, North West University, Mmabatho 2735, South Africa

3 Department of Animal Production, Fort Cox Agriculture and Forestry Training Institute, Middledrift 5685, South Africa; bethwellm@gmail.com

* Correspondence: ntalomalizo@gmail.com (M.N.); onkehawu97@gmail.com (O.H.)

check for updates

Citation: Ntalo, M.; Ravhuhali, K.E.; Moyo, B.; Hawu, O.; Msiza, N.H. Lantana camara: Poisonous Species and a Potential Browse Species for Goats in Southern Africa-A Review. Sustainability 2022, 14, 751. https:// doi.org/10.3390/su14020751

Academic Editor: C. Ronald Carroll

Received: 21 November 2021

Accepted: 5 January 2022

Published: 11 January 2022

Publisher's Note: MDPI stays neutral with regard to jurisdictional claims in published maps and institutional affiliations.

Copyright: (C) 2022 by the authors. Licensee MDPI, Basel, Switzerland. This article is an open access article distributed under the terms and conditions of the Creative Commons Attribution (CC BY) license (https:// creativecommons.org/licenses/by/ $4.0 /)$.

\begin{abstract}
Among the possible impacts of plant invaders on South African biodiversity, water supplies, and rangeland production, Lantana camara is ranked the highest in terms of its environmental impact. Globally, L. camara is regarded as one of the most ecologically and economically destructive invasive alien plants. The spread of L. camara affects the environment and threatens livestock productivity due to its toxicity to animals (especial cattle and sheep) in most semi-arid areas of South Africa. Lantana camara is known to have high concentrations of nutrients that are beneficial to livestock, but most previous research has concentrated on its toxicity. To enrich our knowledge on its nutritive value, further research has to evaluate its dietary impact on the growth and health of different ruminant livestock species, particularly goats. This review evaluates L. camara as a potential browse species for goats in southern Africa, and its adverse effects on goats and other ruminant livestock are also presented. The review describes L. camara and its distribution globally, its poisonous effect to livestock, and potential use as an alternative forage to browsing animals such as goats, which have proved resistant to its harmful traits. The high crude protein content, low fibre and adequate macrominerals for small ruminants makes L. camara a good ruminant protein supplement in semi-arid areas. In addition to other biological control strategies, the prospects of using goats as a biological management tool is discussed. The research will contribute to the understanding of the control measures of L. camara while improving the productivity of small stock, especially goats. This means that a balanced understanding of its nutritional value as a source of protein and its negative impact on the environment should be considered in developing mitigation strategies to arrest its spread. We, therefore, recommend the use of goats in the control of L. camara; however, further studies are needed to limit its toxic effects, and thus improve its value.
\end{abstract}

Keywords: ecosystem; plant invasions; toxicity; alien plants; semi-arid

\section{Introduction}

Invasive alien plant species (IAPS) and climate change have been identified by the International Union for Conversation of Nature [1], as the major challenges to biodiversity worldwide [2,3]. As far as the aforementioned aspects are concerned, greenhouse emissions, extremely warm temperatures combined with a decline in rainfall during the growing season, pose a direct challenge to the distribution of plant species worldwide [4]. Furthermore, although the colonization of natural habitats by alien plant species is a natural phenomenon, recent invasions, among others, are mainly due to humans' activities [5], such as international trades [6]. The introduction of many species beyond their natural range is driven by increased trade and the movement of products around the world [7]. 
Sharma et al. [5] noted that alien plant species have a far greater potential for invasion than indigenous plants. This is because alien plant species may be more efficient competitors that face relatively little pressure from natural predators than indigenous plant species, established in their native land. Lantana camara has been rated as amongst the most invasive species in Queensland, Australia [8]. It is also one of the 100 deadliest IAPS in the world, as acknowledged by the Invasive Species Specialist Group [9].

Ubarn et al. [10] stated that, in Africa, Southern Asia, Australia and Oceania tropical, subtropical and warm temperature areas, L. camara is one of the major ecologically and economically destructive IAPS. This then affects the rangeland quality in the arid and semi-arid regions of Southern Africa where the rangelands are the main source of feed for livestock production. In these areas, livestock production serves as the primary source of income to remote agrarian regions [11]. Nutrition remains a focal factor in livestock production in these regions, with climate change contributing significantly to the major loss in rangeland profitability. Furthermore, during the dry season, grazing lands are prone to overgrazing and drying out, which results in animal feed shortages and inevitably lower levels of protein and energy in fodder. Consequently, the basic nutrient demands for a great number of livestock cannot be met [12]. In addition, in instances of an abundance of low-quality feed, it is of paramount importance to correct that inconsistency through supplementation of the main available fodder with a certain quantity of concentrates. According to Manaye et al. [13] and Gusha et al. [12], for resource-poor farmers, the conventional livestock diets are inaccessible due to the hefty costs, which automatically exclude smallholder livestock producers. As a result, there is a need for more alternative sources of protein to be made available for livestock. Lantana camara can serve as a possible solution by providing an alternative cheap protein source. This review aims to relay the qualities of L. camara as a browse species and its potential use by ruminant livestock, as well as a biological measure of this plant. To date, most studies have focused mostly on the toxicity of Lantana camara to livestock, but little is known about the species' possible nutritional contribution to livestock [12].

\section{Plant Description}

Lantana camara is a deciduous shrub native to tropical America [14], belonging to the Verbenaceae family, popularly referred to as wild or red sage and is recognized as both a weed and a prominent exotic fruit plant [15]. Lantana camara is a vigorous, low, erect or subscandent, triangular stemmed shrub and, when green, is covered in bristly hairs. It is also armed or covered with tiny spines. The height of the weed can range from 1 to $3 \mathrm{~m}$, while the width can widen to $2.5 \mathrm{~m}$. Leaves on both sides are acute or subacute, crenate, ovate, scabrid serrate and rugose above, and have a heavy fragrance. Rough trichomes cover the leaves and stems. Flowers of the weed are small, multicolored, stalked, and densely clustered in flat-topped clusters, with a narrow tube and four short widening lobes on the corolla [14]. The four spreading lobes are green, 3-8 cm stretched, and 3-6 cm tall. It has tiny flowers in clusters. In different shades, the color is generally orange, from white to red and color usually changes as they age. Flowers have yellow throats nearly all year round in the axillary head. The calyx is a thin, slender corolla tube, $6-7 \mathrm{~mm}$ wide and separated into unequal lobes. Inflorescences in the axils of opposite leaves are present in pairs [16]. Mukwevho et al. [17] found thirteen varieties of L. camara in four provinces of South Africa viz. orange-red (015 OR), white pink (021 WP), Hawaii red (017 OR), dark pink (010 DP, $110 \mathrm{DP}, 018 \mathrm{DP})$, white yellow (015 WY), pink (021 P), total pink (021 TP), and light pink (165 LP, 163 LP, 113 LP, 112 LP).

\section{Lantana camara Species Distribution in Southern Africa}

Documentation indicates that L. camara was established in South Africa by 1858 [18], in Cape Town, Western Cape Province (WC), where it rarely spread under Mediterranean climate conditions, and was also documented in 1883 in Durban, KwaZulu-Natal Province (KZN) [10]. Kannan et al. [19] and Shackleton et al. [20] highlighted that L. camara was 
mainly introduced by British colonists around the world, including South Africa, for ornamental purposes. According to the Conservation of Agriculture Resources Act, L. camara is categorized as one of the prohibited dangerous weeds that need to be closely monitored at all costs. Similarly, detrimental to rangelands, water supply and South African biodiversity, L. camara is placed the highest in terms of negative impact on the environment [21]. Many rigorous biological controls in South Africa have been directed to this species [10,22]. In the last two decades, 30 potential biological control agents have been assessed and seven appropriate for release to Africa have been identified [10]. However, only five of these were identified and they do not offer sufficient efficacy because they neither kill the lantana weed nor stop the weed-growing population [22]. Moreover, it is currently naturalized in South Africa in the wet, humid subtropical and temperate regions of Limpopo, Gauteng, Mpumalanga, and KwaZulu-Natal (KZN) [17], as well as the southern coastal regions of the Eastern and Western Cape provinces [23]. Lantana camara invades places such as riverbanks, mountain slopes, valleys, pastures and commercial forests, where it forms dense stands that block entry and use of the invaded areas. Lantana camara has a variety of invasive characteristics that cover its lifespan such as fast growth, rapid reproduction, high dispersal ability, and ecological competence [24].

\section{Impact of L. camara on a New Environment}

Generally, studies have shown that the invasion of alien species such as L. camara threatens not only the ecosystem processes but also the diversity of species at a community and worldwide scale [25,26]. Studies by Bjerknes et al. [27] and Gooden et al. [25] further revealed that alien species have a negative effect on the environment by inhibiting the recruitment of resident native species. The aforementioned sequelea of the alien plant species prevents seedling establishment, growth and modifications to plant pollinator interactions. Thus, such consequences, as noted by Grice, [28] can result in less native plant richness and abundance. The spread and dominance of $L$. camara species within their new ranges often leads to negative impacts on people and the environment $[26,29,30]$. Invasive species can, amongst other things, result in a loss of biodiversity, hinder or even prevent economic development, and reduce the goods and services provided by the ecosystems $[20,29,30]$. Other studies have noted both a positive and negative impact of L. camara in the ecosystem. Lantana camara is recognized for competing with forestry plants and reducing their productivity, and can also help non-timber forest products regenerate [31,32]. Moreover, it minimizes pollinator stress on native plants and serves as a good honey species [32].

\section{Lantana camara as a Poisonous Species to Livestock}

In areas where the accessibility of quality forage to the grazing livestock is insufficient, livestock is forced to graze weeds such as L. camara. Lantana camara is a poisonous plant to livestock, it contains secondary metabolites such as naphthoquinones, irdoid, glycosides, and the most poisonous lantadenes. Lantadenes are pentacyclic triterpenes that cause hepatotoxicity and jaundice, as well as photosensitization [33]. The lantadenes found primarily in the plant leaves have different, harmful effects on different mammals or livestock species. The main constituents of L. camara leaves are lantadene A, lantadene B, lantadene C, as well as lantadene D (mostly in the red flower variety) [34]. Ruminant animals such as buffalo, cattle, and sheep are extremely vulnerable to the lantadenes, whereas goats are slightly resistant to them [35].

Weedy shrubs including L. camara continue to thrive during dry periods [36]. It has been witnessed that cattle, sheep, and goats feed on L. camara [12,36]. Furthermore, throughout its growing season, L. camara is also reported to contain substantial levels of crude protein [37]; thus, in communal areas, L. camara is grazed on heavily by ruminants [12]. Dry conditions impact tropical rangelands and field perceptions show that ruminant livestock such as cattle voluntarily use L. camara. However, studies investigating its nutritional composition are important to inform the management of the species 
and improve livestock production. Despite its nutritive potential for ruminant livestock, L. camara is categorized as amongst the most toxic invasive plant species. There has been less research on the nutritional contribution of L. camara to livestock [38], as it is considered too toxic to livestock. However, the observed browsing behavior by livestock contradicts the conventional perception that L. camara is poisonous to livestock; thus, further research should be carried out to determine whether the species could be considered as a feed resource in deteriorated rangelands.

\section{Anti-Nutritional Factors (ANFs) Associated with Lantana camara}

A study by Haruna et al. [15] revealed that leaves of L. camara can be used as a protein source replacing cowpeas, Bambara groundnut, pigeon pea, and lima bean in livestock feed, but its potential is diminished by reported harm when consumed by animals such as cattle, sheep and horses [12,39], and this might make it necessary for most phyto-chemicals concentration levels to be checked before being fed to cattle and sheep. Moreover, the fruits, leaves and stems of L. camara have toxic compounds embedded within, especially pentacyclic triterpenes [40], as well as lantadene A and B, causing photosensitization, liver and kidney damage, gall bladder paralysis, intestinal haemorrhage and death within one to four days in cattle, sheep, or horses if ingested [23]. Toxic lantadene material exists in L. camara leaves and does not decrease even after multiple weeks of anaerobic microbial reaction under silage-making. Lantana camara leaves have the lowest palatability as fodder [41,42]. Furthermore, in a study conducted by Shamsee et al. [43], it was reported that lantadene $\mathrm{A}$ and $\mathrm{B}$ have the maximum scavenging activity, whereas icterogenin as well as lantadene $C$ have a lower antioxidant effect.

The health consequences of lantadenes are biotransformation by hepatic cytochrome P-450 enzymes into toxins that weaken the bile canaliculi, causing intrahepatic cholestasis as well as impairment of the normal flow of bile [44]. Barik et al. [45] reported that L. camara may be toxic, while substances such as activated charcoal, vaccine, and supportive therapy may help manage its toxic effects, but they are not very effective. Toxicity can be ameliorated by integrating traditional therapeutic techniques with immunological, nanotechnological, and biotechnological approaches [45]. Few authors have reported the occurrence of anti-nutritional factors (ANFs) in L. camara leaves (Table 1). The analysis conducted by Bhuvaneswari and Giri [46] showed that L. camara leaves contain saponins, alkaloids, tannin and phenols. Flavonoids are known to be antioxidants and have been revealed to have anti-inflammatory, antithrombotic, and antiviral effects [46,47]. When large amounts of plant materials, rich in ANFs, are consumed, they decrease animal productivity and are toxic to animals.

Table 1. Anti-nutritional factors in Lantana camara.

\begin{tabular}{lll}
\hline Anti-Nutrient & Composition & Reference \\
\hline Tannins & $3.35 \mathrm{mg} / 100 \mathrm{~g}$ & {$[15]$} \\
Alkaloids & $35.00 \mathrm{mg} / \mathrm{gm}$ & {$[46]$} \\
Phytic acid & $2.52 \mathrm{~g} / 100 \mathrm{~g}$ & {$[48]$} \\
Oxalate & $280.75 \mathrm{mg} / 100 \mathrm{~g}$ & {$[15]$} \\
Saponin & $121.00 \mathrm{mg} / \mathrm{gm}$ & {$[46]$} \\
Trypsin inhibitor & $0.63 \mathrm{mg} / \mathrm{g}$ & {$[48]$} \\
Flavonoids & $165.00 \mathrm{mg} / \mathrm{gm}$ & {$[46]$} \\
\hline
\end{tabular}

\section{The Potential of the Species as an Alternative Feed to Browsing Animals}

The potential of L. camara species and shrubs as an alternative browse source in ruminant nutrition has raised the interest of researchers across the world [49]. According to Gusha et al. [12], throughout periods of feed deficiency, livestock are sustained with local rangeland crop residues as well as grasses, which are frequently nutritionally insufficient. A study conducted in Ethiopia by Getachew and Zeleke [50] revealed that L. camara leaves have high concentrations of protein and could be utilized as a protein source in livestock 
feeds to substitute the conventional protein supplements in livestock diets. Lantana camara is extensively scattered in Kenya and forms an important part of the feed consumed by goats [36]. Livestock consumes L. camara leaves voluntarily on heavily grazed areas due to their high crude protein (CP) content. In the study conducted by Chepape et al. [51], L. camara was identified as the species that is preferred by goats in South Africa. Again, Basha et al. [52] also found that L. camara was among the species with a high selection index by goats in South Africa. The plant has some beneficial effects: for instance, antiinflammatory, antitumor and hepatoprotective action [45]. In a study by Getachew and Zeleke [50], goats were fed different feeds, which contained inorganic concentrates and L. camara hay. The growth rate of goats supplemented with concentrate and L. camara leaf hay was $130 \mathrm{~g} /$ day, while for goats fed with concentrate mix only, it was $100 \mathrm{~g} / \mathrm{day}$. These results suggest that L. camara can be used in animal diets as a protein supplement and can replace feeds that are not normally used in commercially produced animal feed. However, there is a paucity of literature on the use of L. camara as an alternative feed; therefore, there is a need to evaluate L. camara toxicity to goats through the introduction of incremental levels of L. camara in goat diets.

\section{Nutritive Values of Lantana camara}

Livestock feed is becoming expensive because there are only a few, expensive conventional feed sources. Soybeans and groundnuts are needed by both man and livestock [53], and this competition increase their cost. This makes L. camara leaves well-suited as a protein source for livestock feeds. The level of protein (24.8\%) [15], in L. camara leaves compares favourably with certain proteinous plants, i.e., Vigna unguiculata (26\%) [54], Cajanus cajan (24.6\%) [55], Phaseolus lunatus (27.2\%) [56] and Vigna subterranea (23-26\%) [57]. The findings by Mtui et al. [37], indicated that the high CP levels of L. camara varieties, which are abundant in semi-arid rangelands, further highlights L. camara's potential contribution as an important protein supplement to natural grass pastures. Moreover, this species will address the nitrogen deficiencies that are prevalent in most basal roughages, particularly during the dry winter season, when $\mathrm{CP}$ values range between 30 and $70 \mathrm{~g} / \mathrm{kg}$. Aregheore et al. [58] stated that a low CP tends to reduce voluntary feed intake, resulting in inadequate nutrient supply and negatively affecting ruminant livestock growth. Furthermore, with regarding the low $\mathrm{CP}$, the rate of fermentation in the rumen will be decreased, as well as microbial protein production, thus lowering livestock productivity. Studies have shown that livestock feeds with a CP content of less than $6 \%$ are not likely to offer the lowest levels of ammonia needed for peak microbial growth in the rumen [59]. Raw, L. camara leaves have a high CP content, much higher than the minimum $6 \%$ needed for livestock production; therefore, they may be utilized as an alternative protein source [60]. Full microbial action can source about $95 \%$ of the upkeeping of protein requirements in low levels of production. Lawal et al. [61] reported that the CP content present in L. camara is beyond the average range (78-110 g/ kg DM) needed to meet the requirements of lactating goats.

The other important aspect of the results of L. camara varieties' nutritive value is that the measured neutral detergent fibre (NDF) content ranged from low to moderate, between 409.6 and $465 \mathrm{~g} / \mathrm{kg}$ DM [12]. In a study by Mangan [62], it was discovered that high NDF values indicate that the varieties had high cell contents, which positively and strongly correlate with digestibility. Acid detergent fibre (ADF), which estimates lignin as well as cellulose, constituents a small fraction $(<30 \% \mathrm{DM})$. Therefore, it was found that the digestibility of fibre might not be problematic for ruminants. Additionally, Gusha et al. [12] emphasized that the relatively low NDF and ADF values of L. camara provided empirical evidence to support the fact that fibre content in L. camara does not constrain the use of the weed as a feed for livestock that are adept at utilizing diets that are high in NDF and ADF.

Browse plants are recognized as a source of required calcium (Ca), magnesium $(\mathrm{Mg})$ and iron (Fe) and other significant minerals for livestock health. According to Embaby and Mokhtar [43], the fruits of L. camara contained a high amount of potassium (K), followed by phosphorus $(\mathrm{P})$ and sodium $(\mathrm{Na})$. Furthermore, these authors reported the presence of 
Fe (3.01 mg/100 g), Manganese (Mn) (0.38 mg/100 g), copper (Cu) (1.68 mg/100 g), and Zinc $(\mathrm{Zn})(1.05 \mathrm{mg} / 100 \mathrm{~g})$. The study of Mtui et al. [63], revealed that leaves of L. camara had a satisfactory amount of Sulphur (S), $\mathrm{Mg}$, and $\mathrm{Ca}$, which meet the requirements of goats and cows. However, the study established that leaves are a poor source of $\mathrm{P}$ and $\mathrm{Cu}$. Goats and cattle fed these leaves need to be supplemented with these minerals for optimum productivity. Table 2 shows the chemical composition of L. camara, while Table 3 shows the mineral concentration of L. camara leaves.

Table 2. Chemical composition of Lantan camara leaf and fruit.

\begin{tabular}{llll}
\hline Proximate Indices & Concentration $\mathbf{( \% )}$ & Plant Part & References \\
\hline \multirow{2}{*}{ Moisture } & 10.15 & Leaf & {$[15]$} \\
& 17.27 & Fruit & {$[48]$} \\
Crude protein & 24.84 & Leaf & {$[15]$} \\
& 21.32 & Leaf & {$[12]$} \\
& 23.3 & Leaf & {$[50]$} \\
Crude fat & 11.6 & Leaf & {$[52]$} \\
& 4.40 & Leaf & {$[50]$} \\
Dry matter & 2.99 & Leaf & {$[15]$} \\
& 11.00 & Fruit & {$[48]$} \\
Acid detergent fibre & 88.00 & Leaf & {$[50]$} \\
& 90.80 & Leaf & {$[12]$} \\
& 82.73 & Fruit & {$[48]$} \\
& 21.35 & Leaf & {$[12]$} \\
& 15.70 & Leaf & {$[50]$} \\
Acid detergent Lignin & 21.8 & Leaf & {$[52]$} \\
& 44.40 & Leaf & {$[52]$} \\
\hline
\end{tabular}

Table 3. Mineral concentration of Lantana camara leaf [15].

\begin{tabular}{ll}
\hline Minerals & Concentration $(\mathbf{p p m})$ \\
\hline Phosphorus & 0.07 \\
Calcium & 0.54 \\
Manganese & 0.99 \\
Sulfur & 0.73 \\
Potassium & 1.05 \\
Iron & 0.84 \\
Magnesium & 0.43 \\
Copper & 0.53 \\
\hline
\end{tabular}

\section{Management/Control}

Biological invasion research has historically been viewed from a limited ecological angle [64-66]. Research has shown that biological invasion drivers have significant socioeconomic gears that should be considered when designing intervention strategies [66]. Moreover, the regulation of IAPS has been described as a major concern for the South African government. Eleven pieces of national and provincial legislation aimed at controlling the issues surrounding IAPS were passed by $2006[67,68]$. To date, the Conservation of Agricultural Resources Act (CARA, Act No. 43 of 1983) is the most significant of these regulations, with provisions intended to manage the effect of IAPS on the agricultural sector [69]. The South African government adopted the National Environmental Management: Biodiversity Act (NEMBA) in 2004 to reform environmental conservation laws and create a more consistent legislative structure to control IAPS (Act No.10 of 2004). On 1 October 2014, the Alien and Invasive Species Regulations were adopted, giving effect to the Act as a whole $[66,70]$. L. camara is commonly dangerous to biodiversity; in several nations, it results in huge economic losses and is considered one of the most invasive agricultural species [71]. 
Such species need to be controlled or managed. More mechanical, biological, and chemical control efforts were made on L. camara than any other invasive species. Nevertheless, the species is still not under efficient control in several nations [72], because these approaches are not practicable in several situations [38].

According to Urban et al. [10], of all the control measures, biological control is perceived to be an ideal solution for the environment since it is cheap and environmentally friendly. In South Africa, biological control of L. camara begun three decades ago, and 26 biological control agents were released [73]. Recently, Acetaria lantanae, Falconia intermedia, Omphiomyia camarae, Longitarsus bethae, and Coelocephalaoion camarae have been established and deployed as biological control agents. These agents flourish, and they noticeably suppress the development of L. camara in South Africa [74,75]. According to Simelane [76], Longitarsus bethae, and Coelocephalaoion camarae have a low spreading rate; as a result, the release sites are highly susceptible to obliteration by landowners. In South Africa and Swaziland, Acetaria lantanae were successfully established and deployed, notably causing severe damage to flowers of the prone lantana variety [72]. According to Day et al. [38], biological control of L. camara has an advantage over other control measures, comprising a high cost-benefit ratio for effective programs, no species resistance to the agent, as well as maintainable control of the species as agents. Ravhuhali et al. [77], highlighted that, in most countries, the use of livestock (goats) to control invasive species has been practiced in recent years. Despite the fact that goats alone cannot successfully halt the spread of invasive species, few studies have reported the utilization of goats as a management tool. Mayo [78] reported a decline in seed production of Sericea lespedeza where goats were used as a treatment tool. Additionally, Nyamukanza and Scogings [79] reported that goats' continuous browsing on immature sprouts of Vachellia karoo will limit the regrowth of coppices and eliminate the species recruitment.

\section{Summary of the Review}

This review overview focused on the description and distribution of the species, toxicity and its impact on the environment, together with its usefulness to the ecosystem as a browse species. Lantana camara is high in protein, and thus can be valuable as a winter supplement of protein-deficient natural pastures in semi-arid regions. The severity or negative impact on the livestock, especially cattle and sheep, which are susceptible to the plant species, was emphasized in this review. Lantana camara severely decreases the recruitment of native species and also result in death of sheep and cattle with little effect on goats. In order to control L. camara, the contribution of this species to goats' nutrition must be known. In complementing both mechanical and chemical methods, the application of biological controls, such as the use of livestock such as goats, which are resistant to the plant species, can be advantageous to both environment and animal productivity, as it will reduce the spread and growth of the plant and provide high crude protein content to goats.

Author Contributions: Authors M.N., K.E.R., B.M., O.H. and N.H.M. All participated equally to the review article draft. All authors have read and agreed to the published version of the manuscript.

Funding: The project did not receive any external funding.

Institutional Reviewed Board Statement: This study complies with the North-West University Ethics Committee standards and was given an ethical clearance number: NWU-01732-20-A9.

Informed Consent Statement: Not applicable.

Data Availability Statement: Not applicable.

Conflicts of Interest: The authors declare no conflict of interest. 


\section{References}

1. IUCN. The 2008 Review of the IUCN Red List of Threatened Species. 2008. Available online: http://www.iucnredlist.org (accessed on 20 November 2020).

2. Berglund, H.; Järemo, J.; Bengtsson, G. Associations of invasive alien species and other threats to IUCN red list species (Chordata: Vertebrates). Biol. Invasions 2013, 15, 1169-1180. [CrossRef]

3. Ncube, B.; Shekede, M.D.; Gwitira, I.; Dube, T. Spatial modelling the effects of climate change on the distribution of Lantana camara in Southern Zimbabwe. Appl. Geogr. 2020, 117, 102-172. [CrossRef]

4. IPCC. Climate Change 2013: The Physical Science Basis; Contribution of Working Group I to the Fifth Assessment Report of the Intergovernmental Panel on Climate Change; Cambridge University Press: Cambridge, NY, USA, 2013.

5. Sharma, G.P.; Raghubanshi, A.S.; Singh, J.S. Lantana invasion: An overview. Weed Biol. Manag. 2005, 5, 157-165. [CrossRef]

6. Beggs, J.R.; Brockerhoff, E.G.; Corley, J.C.; Kenis, M.; Masciocchi, M.; Muller, F.; Rome, Q.; Villemant, C. Ecological effects and management of invasive alien Vespidae. BioControl 2011, 56, 505-526. [CrossRef]

7. Pagny, F.P.J.; Mevanly, O.; Abrou, N.E.J.; Tiébre, M.-S. Prediction of the potential invasion of Lantana camara L. (Verbenaceae) an exotic plant species in Côte d'Ivoire from a modeling approach. Int. J. Biol. Chem. Sci. 2020, 14, 1241-1261. [CrossRef]

8. Batianoff, G.N.; Butler, D.W. Impact assessment and analysis of sixty-six priority invasive weeds in south-east Queensland. Plant Prot. Q. 2003, 18, 11-15.

9. IUCN. Invasive Species Specialist Group, 100 World's Worst Invasive Alien Species. 2001. Available online: http:/ /www.issg. org/booklet.pdf (accessed on 25 November 2004).

10. Urban, A.J.; Simelane, D.O.; Retief, E.; Heystek, F.; Williams, H.E.; Madire, L.G. The invasive 'Lantana camara L.' hybrid complex (Verbenaceae): A review of research into its identity and biological control in South Africa. Afr. Entomol. 2011, 19, 315-348. [CrossRef]

11. Teklewold, H.; Legese, G.; Alemu, D.; Negassa, A. Live Animal and Meat Export Value Chains for Selected Areas in Ethiopia: Constraints and Opportunities for Enhancing Meat Exports; ILRI Discussion Paper 12; ILRI (International Livestock Research Institute): Nairobi, Kenya, 2008.

12. Gusha, J.; Masocha, M.; Muchaya, K.; Ncube, S. Chemical analysis of the potential contribution of Lantana camara to the nutrition of browsing livestock. Trop. Subtrop. Agroecosyst. 2016, 19, 337-342.

13. Manaye, T.; Tolera, A.; Zewdu, T. Feed intake, digestibility and body weight gain of sheep fed Napier grass mixed with different levels of Sesbania sesban. Livest. Sci. 2009, 122, 24-29. [CrossRef]

14. Priyanka, N.; Joshi, P.K. A review of Lantana camara studies in India. Int. J. Sci. Res. 2013, 3, 1-11.

15. Haruna, S.S.; Ahmed, O.; Johnson, O.T. Nutritional and anti-nutritional composition of Lantana camara leaf. J. Physiol. Biochem. Pharmacol. 2015, 4, 58-60. [CrossRef]

16. Al-Snafi, A.E. Chemical constituents and pharmacological activities of Lantana camara-A review. Asian J. Pharm. Clin. Res. 2019, 12912, 10-20. [CrossRef]

17. Mukwevho, L.; Olckers, T.; Simelane, D.O. Occurrence of different Lantana camara varieties across four South African provinces and their susceptibility to a biotype of the gall-forming mite Aceria lantanae. Biocontrol Sci. Technol. 2018, 28, 377-387. [CrossRef]

18. McGibbon, J. Catalogue of Plants in the Botanic Garden, Cape Town, Cape of Good Hope; Saul Solomon: Cape Town, South Africa, 1858; p. 46.

19. Kannan, R.; Shackleton, C.M.; Shaanker, R.U. Reconstructing the history of introduction and spread of the invasive species, Lantana, at three spatial scales in India. Biol. Invasions 2013, 15, 1287-1302. [CrossRef]

20. Shackleton, R.T.; Witt, A.B.; Aool, W.; Pratt, C.F. Distribution of the invasive alien weed, Lantana camara, and its ecological and livelihood impacts in eastern Africa. Afr. J. Range Forage Sci. 2017, 34, 1-11. [CrossRef]

21. Le Maitre, D.C.; Mgidi, T.N.; Schonegevel, L.; Nel, J.L.; Rouget, M.; Richardson, D.M.; Midgley, C. Plant invasions in South Africa, Lesotho and Swaziland: Assessing the potential impacts of major and emerging plant invaders. An assessment of invasion potential of invasive alien plant species in South Africa. J. Environ. Manag. 2004, 84, 76-96.

22. Taylor, S.; Kumar, L. Impacts of climate change on invasive Lantana camara L. distribution in South Africa. Afr. J. Environ. Sci. Technol. 2014, 8, 391-400. [CrossRef]

23. Baars, J.R. Biological Control Initiatives against Lantana camara L. (Verbenaceae) in South Africa: An Assessment of the Present Status of the Programme, and an Evaluation of Coelocephalapion camarae Kissinger (Coleoptera: Brentidae) and Falconia Intermedia (Distant) (Heteroptera: Miridae), Two New Candidate Natural Enemies for Release on the Weed. Ph.D. Thesis, Rhodes University, Makhanda, South Africa, 2002.

24. Devin, S.; Beisel, J.-N. Biological and ecological characteristics of invasive species: A gammarid study. Biol. Invasions 2007, 9, 13-24. [CrossRef]

25. Gooden, B.; French, K.; Turner, P.J.; Downey, P.O. Impact threshold for an alien plant invader, Lantana camara L., on native plant communities. Biol. Conserv. 2009, 142, 2631-2641. [CrossRef]

26. Vardien, W.; Richardson, D.M.; Foxcroft, L.C.; Thompson, G.D.; Wilson, J.R.U.; Le Roux, J.J. Invasion dynamics of Lantana camara L. (sensu lato) in South Africa. S. Afr. J. Bot. 2012, 81, 81-94. [CrossRef]

27. Bjerknes, A.-L.; Totland, Ø.; Hegland, S.J.; Nielsen, A. Do alien plant invasions really affect pollination success in native plant species? Biol. Conserv. 2007, 138, 1-12. [CrossRef]

28. Grice, A.C. Weeds and the monitoring of biodiversity in Australian rangelands. Austral Ecol. 2004, 29, 51-58. [CrossRef] 
29. Dobhal, P.K.; Kohli, R.K.; Batish, D.R. Impact of Lantana camara L. invasion on riparian vegetation of Nayar region in Garhwal Himalayas (Uttarakhand, India). J. Ecol. Nat. Environ. 2011, 3, 11-22. [CrossRef]

30. Zengeya, T.; Ivey, P.; Woodford, D.J.; Weyl, O.; Novoa, A.; Shackleton, R.; Richardson, D.; van Wilgen, B. Managing conflictgenerating invasive species in South Africa: Challenges and trade-offs. Bothalia-Afr. Biodivers. Conserv. 2017, 47, 1-11. [CrossRef]

31. Shaanker, U.R.; Joseph, G.; Aravind, N.A.; Kannan, R.; Ganeshaiah, K.N. Invasive plants in tropical human-dominated landscapes: Need for an inclusive management strategy. In Bioinvasions and Globalization: Ecology, Economics, Management and Policy; Perrings, C., Mooney, H., Williamson, M., Eds.; Oxford University Press: Oxford, UK, 2010; pp. 202-219.

32. Bhagwat, S.A.; Breman, E.; Thekaekara, T.; Thornton, T.F.; Willis, K.J. A battle lost? Report on two centuries of invasion and management of Lantana camara L. in Australia, India and South Africa. PLoS ONE 2012, 7, e32407. [CrossRef]

33. Sharma, O.P.; Sharma, S.; Pattabhi, V.; Mahato, S.B.; Sharma, P.D. A review of the hepatotoxic plant Lantana camara. Crit. Rev. Toxicol. 2007, 37, 313-352. [CrossRef] [PubMed]

34. Sharma, O.P. Natural products of the Lantane plant: The present and prospects. J. Sci. Ind. Res. 1989, 48, 471-478.

35. Lakshmi, C.S.; Sekhar, C.C. Impact, Management and Uses of Lantana camara-A Noxious Weed. Bull. Environ. Pharmacol. 2018, 7, 170-180.

36. Osuga, I.M.; Abdulrazak, S.A.; Ichinohe, T.; Fujihara, T. Rumen degradation and in vitro gas production parameters in some browse forages, grasses and maize stover from Kenya. J. Food Agric. Environ. 2006, 4, 60-64.

37. Mtui, D.J.; Shem, M.N.; Lekule, F.P.; Ichinohe, T.; Fujihara, T. Evaluation of chemical composition and in vitro gas production of browses collected from Tanzania. J. Food Agric. Environ. 2008, 6, 191-195.

38. Day, M.D.; Wiley, C.J.; Playford, J.; Zalucki, M.P. Lantana: Current Management Status and Future Prospects; ACIAR Monograph No. 102; Australian Centre for International Agricultural Research: Canberra, Australia, 2003.

39. Botha, C.J.; Penrith, M.-L. Poisonous plants of veterinary and human importance in southern Africa. J. Ethnopharmacol. 2008, 119, 549-558. [CrossRef]

40. Kellerman, T.S.; Naudé, T.W.; Fourie, N. The distribution, diagnoses and estimated economic impact of plant poisonings and mycotoxicoses in South Africa. Onderstepoort J. Vet. Res. 1996, 63, 65-90. [PubMed]

41. Negi, G.C.; Sharma, S.; Vishvakarma, S.C.; Samant, S.S.; Maikhuri, R.K.; Prasad, R.C.; Palni, L.M. Ecology and use of Lantana camara in India. Bot. Rev. 2019, 8, 109-130. [CrossRef]

42. Sharma, O.P. How to combat Lantana (Lantana camara) menace-A current perspective. J. Sci. Ind. Res. 1988, $47,611$.

43. Shamsee, Z.R.; Al-Saffar, A.Z.; Al-Shanon, A.F.; Al-Obaidi, J.R. Cytotoxic and cell cycle arrest induction of pentacyclic triterpenoides separated from Lantana camara leaves against MCF-7 cell line in vitro. Mol. Biol. Rep. 2019, 46, 381-390. [CrossRef] [PubMed]

44. Delgado-Altamirano, R.; López-Palma, R.I.; Monzote, L.; Delgado-Domínguez, J.; Becker, I.; Rivero-Cruz, J.F.; Esturau-Escofet, N.; Vázquez-Landaverde, P.A.; Rojas-Molina, A. Chemical constituents with leishmanicidal activity from a pink-yellow cultivar of Lantana camara var. Aculeata (L.) collected in Central Mexico. Int. J. Mol. Sci. 2019, 20, 872. [CrossRef] [PubMed]

45. Barik, S.S.; Sahoo, R.P.; Barik, S.S.; Yadav, M.K. Lantana camara L.: An emerging threat to native flora and livestock: A review. J. Pharmacogn. Phytochem. 2020, 9, 2363-2366.

46. Bhuvaneswari, E.; Giri, R.S. Physicochemical and phytochemical screening in Lantana camara leaves. J. Pharmacogn. Phytochem. 2018, 7, 1962-1966.

47. Kamboh, A.A.; Arain, M.A.; Mughal, M.J.; Zaman, A.; Arain, Z.M.; Soomro, A.H. Flavonoids: Health promoting phytochemicals for animal production-a review. J. Anim. Health Prod. 2015, 3, 6-13. [CrossRef]

48. Embaby, H.E.-S.; Mokhtar, S.M. Chemical composition and nutritive value of lantana and sweet pepper seeds and nabak seed kernels. J. Food Sci. 2011, 76, 736-741. [CrossRef]

49. Fadiyimu, A.A.; Fajemisin, A.N.; Alokan, J.A. Chemical composition of selected browse plants and their acceptability by West African Dwarf sheep. Livest. Res. Rural Dev. 2011, 23, 112-116.

50. Getachew, W.; Zeleke, T. The Potential Contribution of Lantana Camara to the Goat Nutrition: Review and Observation. J. Anim. Husb. Dairy Sci. 2019, 3, 3-8.

51. Chepape, R.M.; Mbatha, K.R.; Luseba, D. Local use and knowledge validation of fodder trees and shrubs browsed by livestock in Bushbuckridge area, South Africa. Livest. Res. Rural Dev. 2011, 23, 132.

52. Basha, N.A.D.; Scogings, P.F.; Nsahlai, I.V. Diet selection of Nguni goats in relation to season, chemistry and physical properties of browse in subhumid subtropical savanna. Small Rumin. Res. 2012, 102, 163-171. [CrossRef]

53. Muhammad, N.O.; Jimoh, F.O.; Nafiu, M.O.; Oloyede, O.B.; Salawu, M.O. Nutrients and Antinutrients Analysis of Albizia lebbeck Seed. Biores. Bull. 2010, 4, 161-165.

54. Ravhuhali, K.E.; Ng'ambi, J.W.; Norris, D. Chemical composition and enzymatic in vitro digestibility of cowpea cultivars and buffalo grass hay grown in Limpopo province of South Africa. Livest. Res. Rural Dev. 2010, 22. Available online: http:/ / www.lrrd.org/lrrd22/9/ravh22170.htm (accessed on 1 February 2021).

55. Sharma, S.; Agarwal, N.; Verma, P. Pigeon pea (Cajanus cajan L.): A hidden treasure of regime nutrition. J. Funct. Environ. Bot. 2011, 1, 91-101. [CrossRef]

56. Baptista, A.; Pinho, O.; Pinto, E.; Casal, S.; Mota, C.; Ferreira, I.M. Characterization of protein and fat composition of seeds from common beans (Phaseolus vulgaris L.), cowpea (Vigna unguiculata L. Walp) and bambara groundnuts (Vigna subterranea L. Verdc) from Mozambique. J. Food Meas. Charact. 2017, 11, 442-450. [CrossRef] 
57. Halimi, R.A.; Barkla, B.J.; Mayes, S.; King, G.J. The potential of the underutilized pulse bambara groundnut (Vigna subterranea (L.) Verdc.) for nutritional food security. J. Food Compos. Anal. 2019, 77, 47-59. [CrossRef]

58. Aregheore, E.M.; Ali, I.; Ofori, K.; Tiria, R. Studies on Grazing Behavior of Goats in the Cook Islands: The Animal-Plant Complex in Forage Preference/Palatability Phenomena. Int. J. Agric. Biol. 2006, 8, 147-152.

59. Nkosi, B.D.; Phenya, J.S.M.; Malebana, I.M.M.; Muya, M.C.; Motiang, M.D. Nutrient evaluation and ruminal degradation of dry matter and protein from amarula (Sclerocarya birrea), macadamia (integrifolia) and baobab (Adansonia digitata L.) oilcakes as dietary supplements for ruminants. Trop. Anim. Health Prod. 2019, 51, 1981-1988. [CrossRef]

60. Wickersham, T.A.; Titgemeyer, E.C.; Cochran, R.C.; Wickersham, E.E.; Moore, E.S. Effect of frequency and amount of rumendegradable intake protein supplementation on urea kinetics and microbial use of recycled urea in steers consuming lowquality forage. $J$. Anim. Sci. 2008, 86, 3089-3099. [CrossRef] [PubMed]

61. Lawal, M.O.; Aderolu, A.Z.; Elegbeleye, O.W.; Oshilaja, O.M. The Nutritive Values of the Leaf Meal and Leaf Protein Concentrate of Some Tropical Weeds. West Afr. J. Fish. Aquat. Sci. 2020, 1, 10-16.

62. Mangan, J.L. Nutritional effects of tannins in animal feeds. Nutr. Res. Rev. 1988, 1, 209-231. [CrossRef] [PubMed]

63. Mtui, D.J.; Lekule, F.P.; Shem, M.N. Mineral concentrations in leaves of nine browse species collected from Mvomero, Morogoro, Tanzania. J. Food Agric. Environ. 2008, 6, 226-230.

64. Sharp, R.L.; Larson, L.R.; Green, G.T. Factors influencing public preferences for invasive alien species management. Biol. Conserv. 2011, 144, 2097-2104. [CrossRef]

65. Vanderhoeven, S.; Piqueray, J.; Halford, M.; Nulens, G.; Vincke, J.; Mahy, G. Perception and understanding of invasive alien species issues by nature conservation and horticulture professionals in Belgium. Environ. Manag. 2011, 47, 425-442. [CrossRef]

66. Cronin, K.; Kaplan, H.; Gaertner, M.; Irlich, U.M.; Hoffman, M.T. Aliens in the nursery: Assessing the attitudes of nursery managers to invasive species regulations. Biol. Invasions 2017, 19, 925-937. [CrossRef]

67. Paterson, A.R. Clearing a path towards effective alien invasive control: The legal conundrum. Potchefstroom Electron. Law J./Potchefstroomse Elektron. Regsblad 2006, 9, 1-56. [CrossRef]

68. Ribot, J.C.; Agrawal, A.; Larson, A.M. Recentralizing while decentralizing: How national governments reappropriate forest resources. World Dev. 2006, 34, 1864-1886. [CrossRef]

69. Badenhorst, A.B. An Investigation into the Compliance of Selected Nurseries and Garden Centres within Kwazulu-Natal Wthekwini and Umsunduzi Geographical Regions, South Africa. In Proceedings of the International Conference on Invasive Alien Species Management, Chitwan, Nepal, 25-27 March 2014; pp. 86-100.

70. Moshobane, M.C.; Mukundamago, M.; Adu-Acheampong, S.; Shackleton, R. Development of alien and invasive taxa lists for regulation of biological invasions in South Africa. Bothalia-Afr. Biodivers. Conserv. 2019, 49, 1-11. [CrossRef]

71. Tripathi, M.; Mishra, V.K.; Kulkarni, N.; Pauranik, M.; Mahavidyalaya, M.G.M. Biological Control of Lantana camara through Spilosoma oblique and Rhizopus Species. Asian J. Exp. Biol. Sci. 2017, 31, 27-30.

72. Day, M.D.; Neser, S.T.E.F.A.N. Factors influencing the biological control of Lantana camara in Australia and South Africa. In Proceedings of the X Symposium on Biological Control of Weeds, Bozeman, MT, USA, 4-14 July 1999; Montana State University: Bozeman, MT, USA, 2000; pp. 897-908.

73. Mukwevho, L. Impact of the Biological Control Agent Aceria lantanae (Cook) (Acari: Trombidiforms: Eriphyidae) on the Invasive Weed Lantana camara L. (Verbenaceae) in South Africa. Master's Thesis, University of KwaZulu Natal, Pietermatzburg, South Africa, 2015

74. Urban, A.J.; Simelane, D.O.; Strathie, L. Lantana herringbone leafminer now in Madagascar. FAO Plant Prot. $2010,83,14$.

75. Heshula, L.U.P.; Hill, M.P. The effect of Lantana camara leaf quality on the performance of Falconia intermedia. BioControl 2011, 56, 925-933. [CrossRef]

76. Simelane, D.O. Influence of soil texture, moisture, and surface cracks on the performance of a root-feeding flea beetle, Longitarsus bethae (Coleoptera: Chrysomelidae), a biological control agent for Lantana camara (Verbenaceae). Environ. Entomol. 2014, 36, 512-517. [CrossRef]

77. Ravhuhali, K.E.; Mudau, H.S.; Moyo, B.; Hawu, O.; Msiza, N.H. Prosopis Species-An Invasive Species and a Potential Source of Browse for Livestock in Semi-Arid Areas of South Africa. Sustainability 2021, 13, 7369. [CrossRef]

78. Mayo, J.M. The Effects of Goats Grazing on Sericea lespedeza. In Symposium Proceedings. Sericea Lespedeza and the Future of Invasive Species; Kansas State University Department of Agronomy: Manhattan, KS, USA, 2000; pp. 14-15.

79. Nyamukanza, C.C.; Scogings, P.F. Sprout selection and performance of goats fed Acacia karroo coppices in the False Thornveld of the Eastern Cape, South Africa. S. Afr. J. Anim. Sci. 2008, 38, 83-90. 